\title{
Penetration of Penicillin into Human Phagocytes Containing Neisseria gonorrhoeae: Intracellular Survival and Growth at Optimum Concentrations of Antibiotic
}

\author{
By D. R. VEALE, HAZEL FINCH AND H. SMITH \\ Department of Microbiology, University of Birmingham, P.O. Box 363 , \\ Birmingham BI5 $2 T T$ \\ AND K. WITT \\ Microbiological Research Establishment, Porton, Wiltshire
}

(Received 26 January 1976)

\begin{abstract}
SUMMARY
Phagocytes obtained from fresh human buffy coat (predominantly polymorphonuclear phagocytes) or from human buffy coat which had been incubated on a glass surface for I to 3 days (predominantly mononuclear phagocytes) were allowed to ingest gonococci, and then incubated with penicillin. More intracellular gonococci were killed at high than at low penicillin concentrations, indicating that penicillin penetrated the phagocytes. This was supported by autoradiography experiments with radiolabelled penicillin.

A pilated, small-colony-forming gonococcal strain survived and multiplied for at least $15 \mathrm{~h}$ in polymorphonuclear phagocytes which were incubated with penicillin at the optimum concentration for killing the extracellular bacteria but not the intracellular ones; whereas a non-pilated, large-colony-forming strain survived for only $\mathrm{Io}$. The former strain survived for at least $6 \mathrm{~h}$ in similar experiments with mononuclear phagocytes. Intracellular survival and growth may be an important facet of the pathogenicity of gonococci.
\end{abstract}

\section{INTRODUCTION}

There is a long established impression (Ovcinnikov, Bohenek \& Litvak, I934; Kellogg et al., I968; Smith, 1968) that gonococci survive and possibly grow intracellularly, because well-staining, healthy-looking organisms are commonly seen in phagocytes of urethral pus. Electron microscopy of pus (Ovcinnikov \& Delektorskij, I97I; Ward, Glynn \& Watt, I972; Farzadegan \& Roth, I975; Novotny, Short \& Walker, 1975) shows that, although many gonococci within polymorphonuclear phagocytes are dead, others are intact and, occasionally, in a state of division. Indeed, Novotny et al. (1975) suggested that gonococci do survive and multiply intracellularly. Similar conclusions were drawn from electron microscopy of gonococci in mouse macrophages (Ota et al., 1975). Whether recently ingested bacteria, which are intact and appear dividing, are subsequently killed, or whether they survive and multiply, can only be decided by counting intracellular gonococci at different times after phagocytosis.

The intracellular viability of gonococci in vitro has been followed by incubating urethral pus, or human buffy coat phagocytes that had ingested gonococci (Watt, 1970; Ward et al., 1972; Gibbs \& Roberts, 1975), with I $\mu \mathrm{g}$ penicillin $/ \mathrm{ml}$ in order to kill extracellular gonococci. As viable gonococci disappeared in $\mathrm{I}$ to $3 \mathrm{~h}$, gonococci seemingly could not survive within human phagocytes. It was assumed that penicillin did not enter the phagocytes, 
since staphylococci survive in the polymorphonuclear (PMN) phagocytes of patients with chronic granulomatous disease in the presence of penicillin or streptomycin (Holmes et al., 1966). However, Thomas, Hill \& Tyeryar (I973), using serum to kill extracellular gonococci, showed that gonococci could survive for at least $2 \mathrm{~h}$ in human PMN phagocytes.

Witt, Veale \& Smith (1976) studied the survival of gonococcal strains within human phagocytes using penicillin $(2 \mu \mathrm{g} / \mathrm{ml})$ and fresh human serum to kill extracellular gonococci. A pilated, small-colony-forming gonococcal strain (BS: resembling virulent Kellogg type 2; Kellogg et al., 1963, 1968) was compared with a non-pilated, large-colony-forming strain (AL: resembling avirulent Kellogg type 4; Kellogg et al., 1963, 1968). Some organisms of strain BS survived intracellularly for $8 \mathrm{~h}$. However, many bacteria (usually over $99 \%$ ) were killed during the first hour of incubation with the bactericidal medium, although electron microscopy showed that most gonococci were intracellular. This rapid destruction of the intracellular gonococci might have been due solely to the activity of the phagocytes but, equally, penicillin might have entered them.

While antibiotics do not penetrate uninfected PMN phagocytes (Mandell, I973) or those infected with staphylococci (Holmes et al., 1966), they enter phagocytes infected with Mycobacterium tuberculosis, Brucella abortus and Listeria monocytogenes (Patterson \& Youmans, 1970; Frost et al., 1972; Cole \& Brostoff, 1975). Penetration of antibiotics into human phagocytes which contain gonococci has not been investigated, but it does not seem to occur for infected HeLa cells (Thayer et al., 1956; Kenny \& Aris, 1969).

Evidence for penicillin entry into human phagocytes containing gonococci has been sought, and the intracellular behaviour of the above pilated and non-pilated strains has been compared using penicillin at the optimum concentration for killing extracellular bacteria without significantly affecting intracellular ones. Preliminary accounts of some of this work have been published (Veale, Smith \& Witt, I975a; Veale, Witt \& Smith, 1975c).

\section{METHODS}

Gonococcal strains. Pilated strain (BS) and non-pilated strain (AL) were derived from Neisseria gonorrhoeae, stored and cultured as described by Veale et al. (I975b).

Culture media. Solid media used for growing the strains and for viable counts in PMN phagocytosis tests were as described by Veale et al. (1975b). For viable counts in mononuclear (MN) phagocytosis tests, the medium contained ( $\%, w / v):$ GC medium base (Difco), 5.6 ; soluble haemoglobin powder (Oxoid), 0.5 ; yeast extract powder (Oxoid), I $\cdot 0$; and glucose, $0 \cdot 7$.

Human phagocytes. Leucocyte populations consisting mainly of PMN phagocytes (about $80 \%$, after settling in Leighton tubes) were obtained as described by Witt et al. (1976) from the layer of leucocytes (buffy coat) which formed above deposited red blood cells when fresh human blood was centrifuged. Populations consisting mainly of $\mathrm{MN}$ phagocytes were produced by allowing human buffy-coat cells to settle on the glass of Leighton tubes and incubating for I to 3 days at $37^{\circ} \mathrm{C}$ under $5 \% \mathrm{CO}_{2} / 95 \%$ air: each tube contained $\mathrm{I} \mathrm{ml}$ suspension (about $3 \times 10^{6}$ leucocytes) in $\mathrm{I}: \mathrm{I}(\mathrm{v} / \mathrm{v})$ Parker medium I99/sheep serum (preheated at $56^{\circ} \mathrm{C}$ for $30 \mathrm{~min}$ ). The medium was changed after 5,24 and $48 \mathrm{~h}$, and during the period most PMN phagocytes became detached from the glass, leaving $10^{3}$ to ${ }^{1} 0^{4} \mathrm{MN}$ phagocytes in each tube. The medium was removed before adding gonococci.

Assessment of intracellular survival in predominantly $P M N$ phagocytes. The test described by Witt et al. (1976) was modified. Equal volumes of suspensions of gonococci $\left(4 \times 10^{7}\right.$ or $\left.2 \times 10^{8} / \mathrm{ml}\right)$ and PMN phagocytes $\left(2 \times 10^{6} / \mathrm{ml}\right)$ in Parker medium 199 containing I0 \% (v/v) isologous human serum (preheated at $56^{\circ} \mathrm{C}$ for $30 \mathrm{~min}$ ) were mixed, and $\mathrm{I} \mathrm{ml}$ 
of mixture was added to each Leighton tube, giving a ratio of either 20 or 100 organisms per PMN phagocyte. Control tubes contained gonococci but no PMN phagocytes. The tubes were gassed with $5 \% \mathrm{CO}_{2} / 95 \%$ air and incubated at $37^{\circ} \mathrm{C}$ for $\mathrm{I} h$ to allow phagocytosis of bacteria to occur, and for the cells to become attached to the glass. The medium was then removed and the deposited cells and bacteria were washed with Earle's saline $(3 \times 5 \mathrm{ml})$ to remove the bulk of the extracellular bacteria. A bactericidal medium $(0.5 \mathrm{ml})$ of fresh human serum $(50 \%, \mathrm{v} / \mathrm{v})$ and penicillin in Parker medium 199 was added, the tubes were re-gassed and incubation continued. When investigating the effect of penicillin on intracellular gonococci, various concentrations of penicillin (o to $20 \mu \mathrm{g} / \mathrm{ml}$ ) were added; but for studies of the intracellular survival of strains $\mathrm{AL}$ and $\mathrm{BS}, 0.4 \mu \mathrm{g}$ penicillin $/ \mathrm{ml}$ was used. After phagocytosis, and periodically after adding the penicillin, duplicate tubes were taken and viable counts were made on the supernatant solutions. Deposits attached to the glass were washed with Earle's saline $(3 \times 5 \mathrm{ml})$, scraped off the glass with a rubber 'policeman' into warm $\left(37^{\circ} \mathrm{C}\right)$ Trypticase soy broth (BBL) containing $10 \%$ preheated sheep serum, agitated (5 s) in a vortex mixer (Fisons Scientific Apparatus, Loughborough, Leicestershire) and plated for viable counts. Penicillinase (Riker Laboratories, Loughborough, Leicestershire) at $1000 \mathrm{u}$. (0.I ml) in Parker medium 199, was added $15 \mathrm{~min}$ before sampling to tubes containing penicillin. Viable counts from tubes in which the medium became alkaline ( $>\mathrm{pH} 8$ ) were not included in the results.

The controls on the phagocytosis test and its interpretation were described by Witt et al. (1976). Accurate measurement of intracellular survival of gonococci was not possible, mainly because it was assessed by viable counts on gradually decreasing populations of infected phagocytes attached to the glass in individual Leighton tubes sampled at intervals, and not by periodic sampling of a single constant phagocyte population. Nevertheless, the test was sufficiently quantitative to detect important differences between strains (Witt et al., I976).

Assessment of intracellular survival in predominantly $M N$ phagocytes. The two main differences between this test and that with PMN phagocyte populations were: (i) gonococci were added to MN phagocytes which had been in the Leighton tube for 2 to 3 days, whereas gonococci and PMN phagocytes were mixed in suspension and then settled in Leighton tubes; and (ii) there were fewer phagocytes on the glass surface $\left(10^{3}\right.$ to $10^{4} \mathrm{MN}$ phagocytes compared to $10^{5} \mathrm{PMN}$ phagocytes), and so the opportunity for phagocytosis was lower. Although similar large numbers of gonococci were added, the number of intracellular organisms in the MN phagocyte deposits was less than in the PMN phagocytes. Nevertheless, observations could be made, though on a smaller scale and over a shorter period.

Gonococci were washed off solid medium with Trypticase soy broth and agitated for 3 min with $3 \mathrm{~mm}$ glass beads in a vortex mixer to disperse clumps. The suspension was diluted to $10^{8}$ organisms in $0.5 \mathrm{ml}$ Parker medium 199 containing $10 \%(\mathrm{v} / \mathrm{v}$ ) isologous preheated human serum and $40 \%(\mathrm{v} / \mathrm{v})$ preheated sheep serum, and then added to Leighton tubes containing $\mathrm{MN}$ phagocytes attached to the glass or to control tubes containing no $\mathrm{MN}$ phagocytes. The tubes were gassed and incubated for $\mathrm{I} h$ to allow phagocytosis to take place. The supernatant solutions were removed and the deposits attached to the glass were washed ( 2 to 4 times) with Earle's saline ( 2 to $5 \mathrm{ml})$. Isologous human serum $(50 \%, \mathrm{v} / \mathrm{v}$; stored at $-70^{\circ} \mathrm{C}$ for 2 to 3 days) and penicillin (various concentrations; see PMN phagocyte test) in Parker medium $199(0.5 \mathrm{ml})$ were added, the tubes were re-gassed and incubation continued. After phagocytosis and penicillin addition, single tubes were removed periodically and viable counts made, as in the PMN phagocyte tests.

Autoradiography. The techniques were described by Rogers (1973). The standard phago- 
cytosis test with PMN phagocytes was used, except that Leighton tubes contained coverslips as for visual counts (Witt et al., 1976), and ${ }^{14} \mathrm{C}$-labelled benzylpenicillin (potassium 6-phenyl[ $\left.{ }^{-14} \mathrm{C}\right]$ acetamidopenicillinate; io to $20 \mathrm{mCi} \mathrm{mmol}^{-1} ; 2$ or $20 \mu \mathrm{g} \mathrm{ml}^{-1}$ ) from The Radiochemical Centre, Amersham, Buckinghamshire, was used with fresh human serum in the bactericidal medium. Leighton tubes received $\mathrm{I} \mathrm{ml}$ of a suspension of $\mathrm{I} \times 10^{6} \mathrm{PMN}$ phagocytes and $\mathrm{I} \times 10^{8}$ gonococci (strain BS) or PMN phagocytes alone (control tubes), and were sampled periodically after the addition of penicillin. After washing with Earle's saline $(3 \times 5 \mathrm{ml})$, coverslips were removed, air dried and stuck (monolayer uppermost) with DPX $(\mathrm{BDH})$ to a microscope slide that had previously been dipped in a solution of gelatin $(0.5 \%, \mathrm{w} / \mathrm{v})$ and $\mathrm{CrK}\left(\mathrm{SO}_{4}\right)_{2} .12 \mathrm{H}_{2} \mathrm{O}(0.05 \%$ w/v). The slide was covered with stripping film (AR Io, Kodak) and exposed for 3 weeks at $4{ }^{\circ} \mathrm{C}$. The autoradiographs were then 'developed, rinsed, fixed, washed in water $(5 \mathrm{~min})$ and stained with Giemsa stain. After removing excess stain with methanol then water, the average number of silver grains on top of PMN phagocytes from all tubes was obtained by counts on 50 to 100 PMN phagocytes per slide; 50 to $80 \%$ of the PMN phagocytes in the infected tubes contained observable gonococci. The average number of silver grains on PMN phagocytes on slides from tubes to which gonococci had not been added provided control values for: (i) the effect of any background activity on the film; (ii) the activity of any ${ }^{14} \mathrm{C}$-labelled penicillin remaining adsorbed on the glass surface below the phagocyte; and (iii) any ${ }^{14} \mathrm{C}$-labelled penicillin adhering to or penetrating the uninfected PMN phagocytes.

\section{RESULTS}

\section{Penetration of penicillin into gonococci-containing PMN phagocytes of human buffy coat; reduction of viable counts}

Although some gonococci settled on the glass surface of control tubes containing no PMN phagocytes, i.e. were extracellular, electron microscopy showed that, after phagocytosis, over $90 \%$ of the gonococci in the phagocytes attached to the glass were intracellular (Witt et al., 1976). Nevertheless, to assess intracellular killing or survival of gonococci in phagocyte deposits that have been incubated with penicillin plus fresh human serum, all gonococci in the deposits and supernatant solutions of control tubes must be killed; and this was achieved (Table I; footnote).

The number of viable gonococci (strain BS) in PMN phagocyte deposits attached to the glass surface fell when incubated for $2 \mathrm{~h}$ with fresh human serum alone. The supernatants from these tubes contained many organisms, and counts increased on further incubation. Adding $0.1 \mu \mathrm{g}$ penicillin $/ \mathrm{ml}$ caused a decrease in the supernatant counts, but at least 0.4 $\mu \mathrm{g} / \mathrm{ml}$ was needed to effect a sufficient suppression of these counts to be sure that gonococci detected in the PMN phagocyte deposits were intracellular. At $2 \mu \mathrm{g}$ penicillin $/ \mathrm{ml}$, the supernatant solutions were devoid of organisms but penetration of penicillin into PMN phagocytes which contained gonococci was indicated by the lower counts in the deposits compared with those exposed to either none or $0 \cdot \mathrm{I} \mu \mathrm{g}$ penicillin/ml (expts I, 2 and 3 , Table I), although they were not consistently below those exposed to $0.4 \mu \mathrm{g} / \mathrm{ml}$. When penicillin was above $2 \mu \mathrm{g} / \mathrm{ml}$ (expts 2, 4 and 5, Table I) gonococci in the deposits were inhibited and sometimes completely destroyed. In a single experiment, not shown in Table I, similar results were obtained with the gonococcal strain AL. At high concentrations, penicillin seemed to enter the phagocytes and kill the gonococci. The decrease of deposit counts in the presence of increasing concentrations of penicillin did not appear to be due to a gross toxic effect of the penicillin on the phagocytes. In three experiments, the ratios of the 


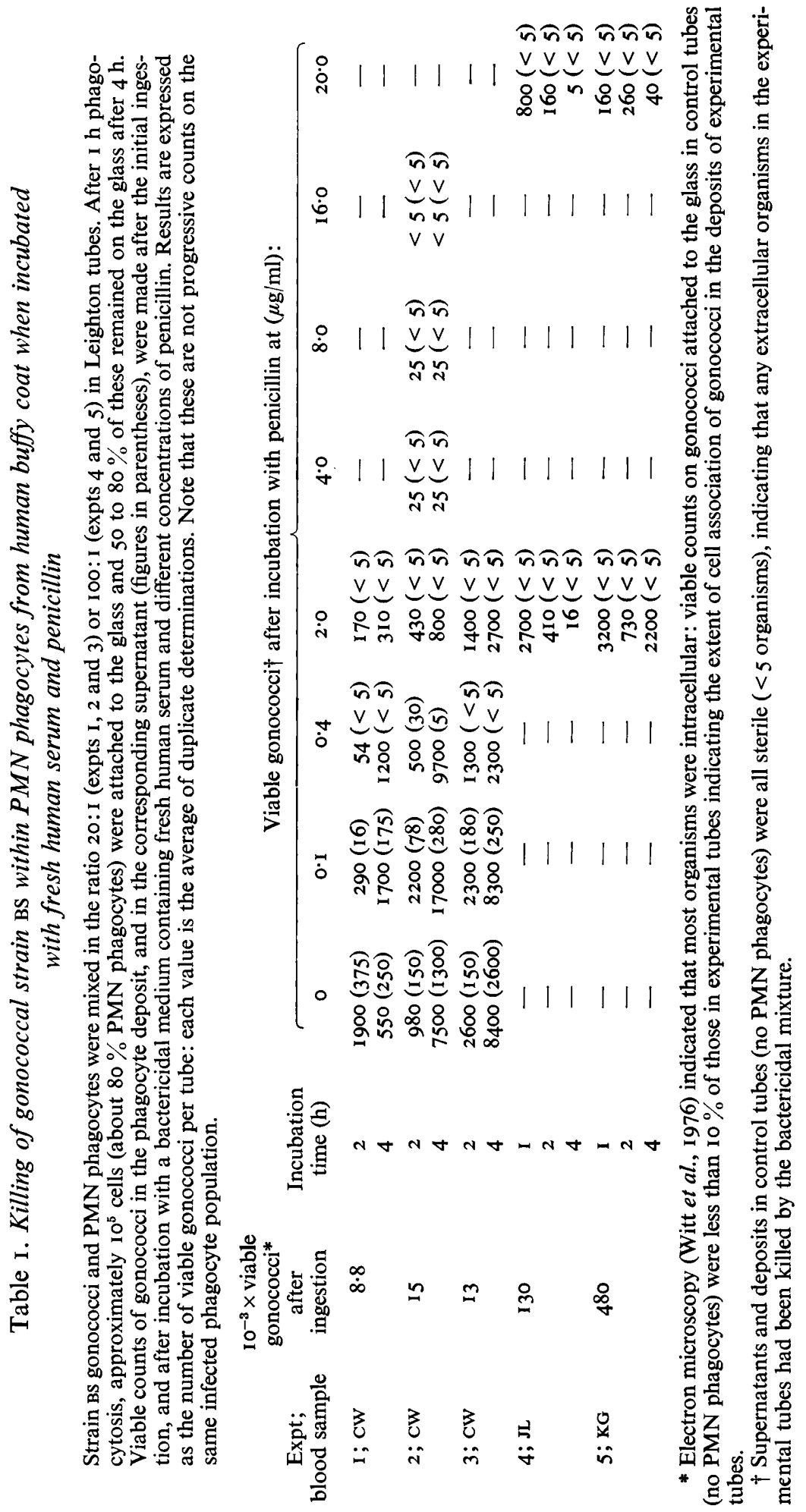




\section{Table 2. Penetration of ${ }^{14} \mathrm{C}$-labelled penicillin into $P M N$ phagocytes of human buffy coat infected with gonococcal strain BS}

Strain BS gonococci and PMN phagocytes were mixed in the ratio I00: I in Leighton tubes. After I h phagocytosis, approximately $10^{5}$ cells (about $80 \%$ PMN phagocytes) were attached to the glass. Bactericidal medium containing fresh human serum and ${ }^{14} \mathrm{C}$-labelled penicillin $(20 \mu \mathrm{g} / \mathrm{ml})$ was added, and incubation continued for I or $2 \mathrm{~h}$. Autoradiographs were prepared as described in Methods. Control tubes containing PMN phagocytes but no gonococci were treated in the same way. Results are expressed as the number of silver grains per PMN phagocyte: each value is an average of representative counts on 50 to 100 PMN phagocytes from each of 1 to 3 tubes \pm the standard error between them.*

Silver grains/PMN phagocyte after incubation for:

\begin{tabular}{|c|c|c|c|c|}
\hline \multirow[b]{2}{*}{$\begin{array}{c}\text { Expt; } \\
\text { blood } \\
\text { sample }\end{array}$} & \multicolumn{2}{|c|}{ I h } & \multicolumn{2}{|c|}{$\widetilde{2 h}$} \\
\hline & $\begin{array}{c}\text { Infected PMN } \\
\text { phagocytes }\end{array}$ & $\begin{array}{c}\text { Uninfected PMN } \\
\text { phagocytes }\end{array}$ & $\begin{array}{c}\text { Infected PMN } \\
\text { phagocytes }\end{array}$ & $\begin{array}{c}\text { Uninfected PMN } \\
\text { phagocytes }\end{array}$ \\
\hline I; KG & $3 \cdot 0$ & $I \cdot 4$ & & \\
\hline $2 ; \mathrm{JL}$ & $I \cdot 3 \pm 0.05$ & $0.6 \pm 0.14$ & $3.2 \pm 0.40$ & $1 \cdot 0 \pm 0.05$ \\
\hline 3 ; CW & $2 \cdot 7 \pm 0.18$ & $2 \cdot I$ & $1.4 \pm 0.25$ & $\mathrm{I} \cdot 3$ \\
\hline $4 ; \mathrm{CW}$ & $2.4 \pm 0.28$ & $\mathrm{I} \cdot 5 \pm 0 \cdot 12$ & $2 \cdot 3 \pm 0.42$ & $2 \cdot 1 \pm 0.20$ \\
\hline $5 ; \mathrm{JL}$ & $I \cdot 3 \pm 0.15$ & $0.5 \pm 0.05$ & $I \cdot 2 \pm 0.58$ & $0.7 \pm 0.12$ \\
\hline
\end{tabular}

* An analysis of variance showed that: (i) in individual comparisons, although the average number of silver grains associated with the gonococci-infected phagocytes was greater than the number associated with non-infected phagocytes in all experiments, it was only significantly so $(P<0.05)$ in expts $2(2 \mathrm{~h}$ incubation) and 5 ( $\mathrm{l}$ h incubation); (ii) when the results for either $\mathrm{I} \mathrm{h}$ or $2 \mathrm{~h}$ incubation from the five experiments were pooled, the difference was significant $(P<0.05)$ for both incubation times; and (iii) when all the results from $\mathrm{I} h$ and $2 \mathrm{~h}$ incubations were pooled, the difference was even more significant $(P<0.01)$.

number of PMN phagocytes attached to the glass surface in the presence of gonococci after $4 \mathrm{~h}$ incubation with $20 \mu \mathrm{g}$ penicillin/ml to the number after incubation with $2 \mu \mathrm{g} / \mathrm{ml}$ were $I \cdot 2, I \cdot I$ and $2 \cdot 0$. Human serum did not penetrate the PMN phagocytes because varying the proportion of serum (from I to $100 \%, v / v$ ) in the bactericidal medium did not affect the viable counts of gonococci in the PMN phagocyte deposits.

In Expts I, 2 and 3 (Table I), the deposit counts $4 \mathrm{~h}$ after adding fresh human serum (with or without penicillin) were often higher than after $2 \mathrm{~h}$. This increase was greatest when penicillin was either absent, or present at only $0.1 \mu \mathrm{g} / \mathrm{ml}$ but also occurred at 0.4 and 2.0 $\mu \mathrm{g}$ penicillin $/ \mathrm{ml}$. This was the first indication of intracellular multiplication of gonococci (see below).

\section{Penetration of radiolabelled penicillin into gonococci-containing PMN phagocytes of human buffy coat}

In autoradiographical experiments using $20 \mu \mathrm{g}{ }^{14} \mathrm{C}$-labelled penicillin/ml (Table 2), the number of silver grains associated with the infected PMN phagocytes after I and $2 \mathrm{~h}$ was higher than the number associated with similarly treated uninfected phagocytes. However, the difference was not large and the possibility that penicillin might also have penetrated the uninfected PMN phagocytes cannot be ruled out. In experiments using $2 \mu \mathrm{g}{ }^{14} \mathrm{C}$-labelled penicillin/ml, no significant increase in the number of silver grains associated with infected phagocytes was detected.

\section{Intracellular behaviour of gonococcal strains BS and $\mathrm{AL}$ in human PMN phagocytes}

Using $0.4 \mu \mathrm{g}$ penicillin $/ \mathrm{ml}$, the lowest concentration which consistently destroyed extracellular organisms, some intracellular organisms may have been killed (see Table I). In four 
Table 3. Behaviour of gonococcal strains $\mathrm{BS}$ and $\mathrm{AL}$ within PMN phagocytes from human buffy coat incubated with fresh human serum and penicillin

Strains BS and AL gonococci and PMN phagocytes were mixed in the ratio 20:I (50: I in expt 4) in Leighton tubes. After I h phagocytosis, approximately $10^{5}$ cells (about $80 \%$ PMN phagocytes) were attached to the glass; I0, 20 and $34 \%$ of these cells remained attached after $\mathrm{I} 5 \mathrm{~h}$ in expts $\mathrm{I}$, 2 and 3, respectively, and $50 \%$ remained attached after $8 \mathrm{~h}$ in expt 4 . Viable counts of gonococci in the PMN phagocyte deposit and in the corresponding supernatants (figures in parentheses) were made after the initial ingestion, and after incubation with a bactericidal medium containing fresh human serum and penicillin $(0.4 \mu \mathrm{g} / \mathrm{ml})$. Where no figures are given in parentheses, the supernatants were sterile ( $<5$ organisms). Results are expressed as the number of viable gonococci per tube: values are the average of duplicate determinations unless indicated otherwise. Note that these are not progressive counts on the same infected phagocyte population.

\begin{tabular}{|c|c|c|c|c|c|c|c|c|}
\hline \multirow{2}{*}{$\begin{array}{c}\text { Expt; } \\
\text { blood } \\
\text { sample }\end{array}$} & \multirow[b]{2}{*}{ Strain } & \multirow{2}{*}{$\begin{array}{c}\mathrm{I}^{-3} \times \text { viable } \\
\text { gonococci } \\
\text { after } \\
\text { ingestion }\end{array}$} & \multicolumn{6}{|c|}{ Viable gonococci $\dagger$ after incubation with penicillin for: } \\
\hline & & & $2 \mathrm{~h}$ & $5 \mathrm{~h}$ & $8 \mathrm{~h}$ & Io $\mathrm{h}$ & $12 \mathrm{~h}$ & I5 h \\
\hline $\mathrm{I} ; \mathrm{JL} / \mathrm{VW}$ & $\begin{array}{l}\text { BS } \\
\text { AL }\end{array}$ & $\begin{array}{l}13 \\
18\end{array}$ & $\begin{array}{l}200^{*} \\
<5\end{array}$ & $\begin{array}{r}6 \\
<5\end{array}$ & $\begin{array}{l}180 \\
15^{*}\end{array}$ & $<5^{*}$ & $\begin{array}{l}670^{*} \\
<5\end{array}$ & $\begin{array}{l}500 \\
<5\end{array}$ \\
\hline 2; CW & $\begin{array}{l}\text { BS } \\
\text { AL }\end{array}$ & $\begin{array}{r}\text { II } \\
9\end{array}$ & $\begin{array}{r}200 \\
5\end{array}$ & $\begin{array}{c}4100^{*} \\
5\end{array}$ & $\begin{array}{l}5400(210) \\
27\end{array}$ & $\begin{array}{l}9700^{*} \\
250\end{array}$ & $\begin{array}{c}5300 \\
<5\end{array}$ & $\begin{array}{r}1600 \\
<5\end{array}$ \\
\hline $3 ; \mathrm{cw}$ & $\begin{array}{l}\text { BS } \\
\text { AL }\end{array}$ & $\begin{array}{l}32 \\
32\end{array}$ & $\begin{array}{l}90 \\
27(5)\end{array}$ & $\begin{array}{c}340(9) \\
4\end{array}$ & $\begin{array}{l}80^{*} \\
<5\end{array}$ & $\begin{array}{l}120^{*}(20) \\
<5\end{array}$ & $\begin{array}{l}150^{*} \\
<5\end{array}$ & $\begin{array}{l}150^{*} \\
<5\end{array}$ \\
\hline $4 ; \mathrm{KG}$ & $\begin{array}{l}\text { BS } \\
\text { AL }\end{array}$ & $\begin{array}{r}89 \\
190\end{array}$ & $\begin{array}{c}890 \\
2500(6)\end{array}$ & - & $\begin{array}{l}4800^{*} \\
<50\end{array}$ & - & - & - \\
\hline
\end{tabular}

* Results from a single Leighton tube.

† Supernatants and deposits in control tubes (no PMN phagocytes) were all sterile ( $<5$ viable organisms), indicating that any extracellular organisms in the experimental tubes had been killed by the bactericidal mixture.

experiments, the survival of strains BS and AL in PMN phagocytes was compared over I5 $\mathrm{h}$ (Table 3). After an initial decrease, the number of viable strain BS gonoccoci multiplied over this period. Strain AL decreased to low numbers in $2 \mathrm{~h}$ (except in expt 4 ) and could not be detected after Io $\mathrm{h}$. Similar results (not shown) were obtained using $0.2 \mu \mathrm{g}$ penicillin/ $\mathrm{ml}$, although in this case more supernatant solutions contained gonococci (indicating that not all extracellular organisms had been killed) and gonococcal counts on the phagocyte deposits were higher than those shown in Table 3. In assessing the results shown in Table 3, it should be remembered that: (i) the values at each time point were obtained from individual Leighton tubes and not from progressive counts on the same population; and (ii) by $\mathrm{I} 5 \mathrm{~h}$ there was a 65 to $90 \%$ reduction in the number of PMN phagocytes (and therefore of their contained gonococci) adhering to the glass surface.

\section{Effect of parasitization with gonococci on the attachment of human PMN phagocytes to the surface of Leighton tubes}

In the phagocytosis period, interaction of gonococci with PMN phagocytes appeared to promote the attachment of the PMN phagocytes to glass. Thus, in four out of nine standard phagocytosis tests, the numbers of PMN phagocytes adhering to control tubes (PMN phagocytes alone) were less than $10 \%$ of those adhering to experimental tubes (gonococci and PMN phagocytes), and in four others, the numbers adhering to control tubes were between 10 and $50 \%$ of those adhering to experimental tubes. 


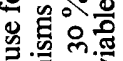

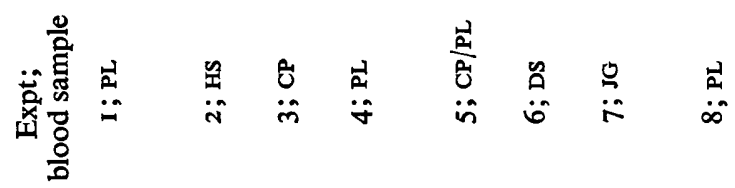




\section{Penetration of penicillin into gonococci-containing $M N$ phagocytes of human buffy coat}

When viable gonococci within human $\mathrm{MN}$ phagocytes were incubated with various concentrations of penicillin, they showed a sharp decline in the first $2 \mathrm{~h}$ even when no penicillin was added (Table 4). Fresh human serum alone was clearly sufficient to destroy extracellular organisms but was aided considerably by $0.4 \mu \mathrm{g}$ penicillin $/ \mathrm{ml}$. The numbers of $\mathrm{MN}$ phagocytes attached to the glass $\left(10^{3}\right.$ to $\left.10^{4}\right)$ were lower than those $\left(10^{5}\right)$ in the PMN phagocyte tests and visual counts indicated that many gonococci remained extracellular. As in the PMN phagocyte experiments, viable gonococci in phagocytes attached to the glass surface decreased with increasing penicillin concentrations indicating uptake of the antibiotic. The low numbers of gonococci detected in deposits incubated with 0.4 or more $\mu \mathrm{g}$ penicillin/ml suggested that $\mathrm{MN}$ phagocytes might be more permeable to penicillin than PMN phagocytes (see Table I), but there was not enough data to be sure of this.

\section{Intracellular survival of gonococcal strain BS in human $M N$ phagocytes}

Observing the intracellular behaviour of gonococci in MN phagocytes was more difficult than in PMN phagocytes because of the small numbers of the former that remained attached to the glass after removal of the latter, and the possible greater permeability of $\mathrm{MN}$ phagocytes to penicillin. Thus, the numbers of gonococci surviving in phagocyte deposits after incubation with sufficient penicillin $(0.4$ or $2 \mu \mathrm{g} / \mathrm{ml})$ to kill all organisms in the supernatant solution were usually small, even after $2 \mathrm{~h}$ incubation with the bactericidal mixture (Table 4). Nevertheless, despite any subsequent effect of penicillin penetration that occurred at these concentrations, intracellular survival of gonococci (strain Bs) occurred for 4 to $6 \mathrm{~h}$. This conclusion was supported by the results obtained with $0 . \mathrm{I}$ and $0.2 \mu \mathrm{g}$ penicillin $/ \mathrm{ml}$ which, although insufficient to remove all extracellular organisms, considerably reduced them (Table 4). On the other hand, conclusive evidence for an increase in intracellular gonococci comparable to that obtained for the PMN phagocyte experiments (Table 3) was not forthcoming. In expts $\mathrm{r}$ to 4 (Table 4), the deposit counts increased from 2 to $6 \mathrm{~h}$, but only at penicillin concentrations which did not remove all extracellular organisms.

\section{DISCUSSION}

The results show that penicillin can penetrate human buffy coat PMN and MN phagocytes and kill intracellular gonococci. This effect was marked when penicillin was present at greater than $2 \mu \mathrm{g} / \mathrm{ml}$ but probably also occurred at lower concentrations, although it was difficult to detect at concentrations below $0.4 \mu \mathrm{g} / \mathrm{ml}$ which were insufficient to kill extracellular organisms. The autoradiographical experiments indicated that ${ }^{14} \mathrm{C}$-labelled penicillin penetrated gonococci-infected phagocytes although these experiments were less sensitive than the viable count experiments. An external penicillin concentration of $20 \mu \mathrm{g} / \mathrm{ml}$ was required to obtain significant differences between counts of silver grains associated with infected and with control PMN phagocytes. The appreciable numbers of silver grains associated with the latter might have been due to 'background' influences, but the possibility of penicillin uptake cannot be ruled out.

That penicillin enters human phagocytes containing gonococci may explain why previous workers detected only destruction of gonococci in phagocytes incubated with I $\mu \mathrm{g}$ penicillin/ $\mathrm{ml}$. It could also explain the success of the antibiotic in treating gonorrhoea where many bacteria are intracellular. Ovcinnikov, Delektorskij \& Afansev (1974) reported greatly 
increased destruction of intracellular gonococci in the urethral pus of patients after treatment with penicillin. Some damaged organisms may have been phagocytosed after being affected by penicillin but equally penicillin may have penetrated and killed gonoccoci that had been ingested before antibiotic treatment. The penicillin uptake may have been caused by the gonococci stimulating pinocytosis or may have occurred during further phagocytosis of dead extracellular gonococci. Alternatively, gonocccci may have a cytotoxic action on the cells, as Frost et al. (1972) postulated to explain the increased permeability of bovine PMN phagocytes to streptomycin following treatment with large quantities of killed Brucella abortus. However, we found that gonococci increased the initial adherence of PMN phagocytes to glass indicating a change in the phagocytes' surface properties, but failed to detect any gross cytotoxic action of gonococci such as subsequent large scale detachment of the phagocytes from the glass.

At low concentrations of penicillin $(0.4 \mu \mathrm{g} / \mathrm{ml})$, the pilated, small-colony-forming BS strain, which resembled virulent Kellogg type 2 organisms and infected subcutaneously implanted chambers in guinea pigs (Veale et al., 1975b), not only survived but appeared to multiply during the $15 \mathrm{~h}$ period within human PMN phagocytes. Under the same conditions the non-pilated, large-colony-forming AL strain, which resembled a virulent Kellogg type 4 organisms and could not infect guinea-pig chambers (Veale et al., 1975b), survived at a much lower level than the BS strain and could not be detected after $10 \mathrm{~h}$. In one experiment, there was evidence of multiplication of the small numbers of survivors between 5 and $10 \mathrm{~h}$, but thereafter all organisms were destroyed. Possibly the killing action of the phagocytes selected a few resistant AL organisms which had characteristics similar to the BS strain. Survival of the BS strain was detected in human MN phagocytes but over a shorter period. The scale of these tests was restricted by the numbers of cells remaining attached to glass surfaces and possibly by their greater penetration by penicillin.

The difference in capacity of BS and AL to survive and grow intracellularly in PMN phagocytes reflects their difference in infectivity for guinea-pig subcutaneous chambers (Veale et al., 1975b) and their probable difference in virulence for man (by analogy with the Kellogg types). It should also be remembered that, in the tests described, the observed intracellular survival and multiplication of gonococci was decreased by possible penetration of penicillin and by phagocytes becoming detached from the glass surface. In patients not treated with antibiotic, these restrictions do not apply, and intracellular survival and growth could be greater than detected in these tests, assuming that phagocytes in the urogenital tract behave in the same way as buffy coat phagocytes. When our evidence is coupled with that from electron microscopy of urethral pus (Novotny et al., 1975), it appears that resistance to intracellular destruction by phagocytes is an important facet in the pathogenicity of Neisseria gonorrhoeae in man.

We thank our blood donors and also Miss A. F. Munday for technical assistance. 


\section{REFERENCES}

Cole, J. \& BRostoff, J. (1975). Intracellular killing of Listeria monocytogenes by activated macrophages (Mackaness system) is due to antibiotic. Nature, London 256, 515-517.

FARZADEghaN, H. \& Roth, I. L. (1975). Scanning electron microscopy and freeze-etching of gonorrhoeal urethral exudate. British Journal of Venereal Disease 5r, 83-91.

Frost, A. L., Smith, H., Witt, K. \& KePpie, J. (I972). The chemical basis of the virulence of Brucella abortus. X. A surface virulence factor which facilitates intracellular growth of Brucella abortus in bovine phagocytes. British Journal of Experimental Pathology 53, 587-596.

GIBBS, D. L. \& RoBerTs, R. B. (I975). The interaction in vitro between human polymorphonuclear leukocytes and Neisseria gonorrhoeae cultivated in the chick embryo. Journal of Experimental Medicine I4I, I55-17I.

Holmes, B., Quie, P. G., Windhorst, D. B., Pollara, B. \& Good, R. A. (1966). Protection of phagocytosed bacteria from the killing action of antibiotics. Nature, London 2ro, I I3I-I I32.

Keilogg, D. S., JR, Peacock, W. L. JR, Deacon, W. R., Brown, L. \& Pirkle, C. I. (I963). Neisseria gonorrhoeae. I. Virulence genetically linked in clonal variation. Journal of Bacteriology 85, I 274-1 279.

Kellogg, D. S., JR, Cohen, I. R., Norins, L. C., Schroeter, A. L. \& Reising, G. (1968). Neisseria gonorrhoeae. II. Colonial variation and pathogenicity during 35 months in vitro. Journal of Bacteriology 96 , 596-605.

KenNY, C. P. \& ARIS, B. J. (1969). The infection of tissue cells in culture with Neisseria gonorrhoeae. Canadian Journal of Public Health 6o, 34.

Mandell, G. L. (1973). Interaction of intraleucocytic bacteria and antibiotics. Journal of Clinical Investigation 52, I673-1679.

Novotny, P., SHORT, J. A., \& WALKER, P. D. (1975). An electron-microscope study of naturally occurring and cultured cells of Neisseria gonorrhoeae. Journal of Medical Microbiology 8, 413-427.

Ota, F., Morita, J., Yoshida, N., Ashton, F. \& Diena, B. (1975). Studies on gonococcal infection. I. Electron microscope studies on phagocytosis of Neisseria gonorrhoeae by macrophages. Japanese Journal of Microbiology 19, I49-155.

Ovcinnikov, N. M. \& DelektorskiJ, V. V. (I97I). Electron microscope studies of gonococci in the urethral secretions of patients with gonorrhoea. British Journal of Venereal Disease 47, 419-439.

Ovcinnikov N. M., Bohenek, A. A. \& Litvak, P. B. (I934). Phagocytosis or endocytobiotics, its significance in gonorrhoea. Urologiya Ir, 84-88.

Ovcinnikov, N. M., DelektorskiJ, V. V. \& Afansev, B. A. (I974). Electron microscopy of gonococci in the urethral secretions of patients with gonorrhoea treated with penicillin and erythromycin. British Journal of Venereal Disease 50, 179-194.

Patterson, R. J. \& Youmans, G. P. (1970). Multiplication of Mycobacterium tuberculosis within normal and 'immune' mouse macrophages cultivated with and without streptomycin. Infection and Immunity $\mathbf{I}$, $30-40$.

Rogers, A. W. (1973). Techniques of Autoradiography, and ed. Amsterdam: Elsevier.

SMITH, H. (I 668 ). Biochemical challenge of microbial pathogenicity. Bacteriological Reviews 32, I64-184.

Thayer, J. D., Perry, M. I., Field, F. W. \& Garson, W. (1956). Failure of penicillin, chloramphenicol, erythromycin and novobiocin to kill phagocytosed gonococci in tissue culture. Antibiotics Annual 513-517.

Thomas, D. W., Hill, J. C. \& Tyeryar, F. J., JR (I973). Interaction of gonoccoci with phagocytic leukocytes from men and mice. Infection and Immunity 8, 98-I04.

Veale, D. R., Smith, H. \& WitT, K. (I975a). Penetration of penicillin into human phagocytes containing gonococci. Lancet i, 306-308.

Veale, D. R., SMith, H., WitT, K. \& Marshali, R. B. (I975b). Differential ability of colonial types of Neisseria gonorrhoeae to produce infection and an inflammatory response in subcutaneously perforated plastic chambers in guinea-pigs and rabbits. Journal of Medical Microbiology 8, 325-335.

Veale, D. R., WITT, K. \& SMITH, H. (I975c). Penetration of penicillin into human phagocytes containing gonococci: intracellular survival at minimal concentrations of antibiotic. Proceedings of the Society for General Microbiology 2, 75.

WARD, M. E., GLYNN, A. A. \& WATT, P. J. (1972). The fate of gonococci in polymorphonuclear leukocytes: an electron microscope study of the natural disease. British Journal of Experimental Pathology 53, 289-294.

WATT, P. J. (I970). The fate of gonococci in polymorphonuclear leukocytes. Journal of Medical Microbiology 3, 501-509.

WITT, K., VEAle, D. R. \& SMIth, H. (1976). Resistance to ingestion and digestion of Neisseria gonorrhoeae by phagocytes of human buffy coat. Journal of Medical Microbiology 9, I-I 2. 